\title{
Strategy for Strengthening Creative Economy Based on Digital Entrepreneurship Through the Pentahelix Model in Deli Serdang Regency (Case Study in Percut Sei Tuan District)
}

\author{
Dina Arfianti Siregar ${ }^{1 *}$, Cut Nizma ${ }^{2}$, Darwin S.H. Damanik ${ }^{3}$ \\ ${ }^{1}$ Accounting Major, Politeknik Negeri Medan, Indonesia \\ ${ }^{2}$ Banking and Finance Major, Politeknik Negeri Medan, Indonesia \\ ${ }^{3}$ Banking and Finance Major, Politeknik Negeri Medan, Indonesia \\ *Corresponding Author: dinaarfianti28@gmail.com
}

\begin{abstract}
The purpose of this research is to find out the obstacles faced by business actors in strengthening the creative economy and determine what strategies are most appropriate in strengthening the creative economy. This type of research is a qualitative research with 15 research informants. Through interactive data analysis with interview techniques and focus group discussions, information related to the object of research was obtained. The results of the study show that there are obstacles faced by business actors, namely the inability to sell products using digital technology due to lack of knowledge and understanding of digital entrepreneurship, limited raw materials, lack of business capital, the role of media in online marketing and promotion has not been maximized, collaboration is not optimal between academics, business, government, community and media. The best strategy that can be applied is a growth strategy through the role of the government which is enthusiastically hold digital entrepreneurship training to improve marketing skills of business actors and sales volume, actively make promotion via digital marketing that can reach a larger number of target audiences, improve product quality, increase motives and product characteristics through innovation and creativity, actively hold exhibitions and marketing events, and conduct optimal collaboration between academics, business, government, communiy and media.
\end{abstract}

Keywords: creative, digital entrepreneurship, pentahelix model

\section{Introduction}

Economic growth is shown through the ability of a country to produce products and services from the economic resources used so that in the end it can be seen from the level of welfare of its population. Factors that can indicate an increase in the economy can be seen from the amount of real income that the country gets. (Sukirno, 2016). The Central Bureau of Statistics stated that in the last quarter the level of the economy was below zero, which was around 1.1-1.8 percent. Based on this, if we look at the current development of the number of MSMEs in Indonesia, according to the Central Statistics Agency, the number of existing MSMEs is already at 63 million and reaches $99.8 \%$ of businesses which are very helpful in improving the Indonesian economy (bps.go. id, 2020).

Indonesia has been facing the COVID 19 outbreak for more than a year starting in March 2020 until now, and it is not yet known when it will end. There have been many victims due to this pandemic, and the number of cases of patients affected by COVID 19 continuously increase. This condition certainly affects to people's lives, including the economic sector. There are a lot of declines in the level of public consumption, a decrease in income, which lead to a decline in economic growth. 
The MSME sector which is expected to be able to support the economy, is impacted by the COVID-19 pandemic. The reduced purchasing power of the people due to limited interactions, which have always been carried out in sales activities, has become something that is impossible to do. It causes a decline in economic activity, a decline in people's purchasing power, a decline in economic growth.

There are about $30 \%$ of the MSMEs sector that has been disrupted due to this pandemic and 50-60\% from that amount have managed to respond this uncertainty condition through innovations, such as the use of digital technology in selling their products so that it could be able to increase sales turnover up to $26 \%$ (Santia, 2020).

Deli Serdang is an area that produces various superior sectors that are the pride of the area. There are 16 creative economic sectors in MSMEs, which is in this case Deli Serdang focuses on 4 (four) creative economic sectors which are the leading sectors, namely performing arts, crafts, culinary, and fashion. The Deli Serdang government always tries to make breakthroughs to increase the activity of MSMEs such as provide assistance in training, creative/production houses, and make training for 25 Deli Serdang Leading Entrepreneurs, promotion programs for superior products by building marketing buildings for regional superior products, as well as development programs. For superior product and one village one product. In addition, collaboration with the Creative Economy Agency (Bekraf) was also carried by signing of an MoU as the efforts to develop the creative economy. It is hoped that the movement of MSMEs will not only reach the domestic market, but also the international market, which is it is a big challenge especially for MSMEs and the Deli Serdang district government in general. It needs cooperation among business, goverment, community, academics and media (Asmara, 2019).

Currently there are 8.2 million (13\%) MSMEs that have tended using online social media and $87 \%$ are still offline. It is needed more efforts from the government to formulate various policies in order to move MSMEs so that MSME development is faster in spurring economic growth (bps.go.id. 2020).

There are still various problems faced by MSMEs beside activities carried out by the Deli Serdang Government, especially in the pandemic, such as there has been a significant decline in sales turnover from MSMEs business in Deli Serdang Regency due to a decrease in demand for goods/product, businessman has loss in their selling activity, etc. Based on interviews conducted by the research team to coconut shell craftsmen, mangrove batik businesses, and banana chips businesses in Percut Sei Tuan, as one of the sub-districts in Deli Serdang district, they revealed that there was a decline in average sales of $40-50 \%$ and they still hope there is guidance from the local government on how to be able to sell goods in limited conditions. So far, they sell their goods mostly by offline, and a small part through online media such as whatsapp and facebook, but they feel that it has not run optimally because there are still deficiency of other details related to promotion and marketing such as the lack of ability to make products displayed. on homepage, as well as the possibility of collaborating with other parties in marketing their products. From the background above, the problems in this study are: a. What are the obstacles faced by business actors in strengthening the creative economy? b. What strategies are most appropriate in strengthening the creative economy?

There are some references to support this research, namely:

1. Digital Entrepreneurship

Allen, J.P. (2019) defines digital entrepreneurship as entrepreneurship related to the world of digitalization which has so many resources that will make it easier for people to carry out marketing and sales activities, better promotions, the ability to cooperate with 
advertising companies in promoting products/services as well as the use of artificial intelligence..

\section{E-commerce}

E-commerce is the activity of buying and selling products electronically using computer media (Laudon \& Traver, 2017). Initially this electronic commerce was an online retail sales system, but over time it became an activity that made it easier and became a trend in the trade sector. Through this system, it has been known openly the prevailing price level, fast access, effective trading activities, and the company's relationship with vendors. Some examples of e-commerce named Tokopedia, Shoppee, and Gojek.

\section{Digital Marketing}

This model is a marketing and promotional activity carried out online through social media such as Facebook and Instagram (Purwana et al., 2017).

Digital Marketing is very helpful for marketers in marketing their products because of their ability to manage the content in the application so that the promotion process runs more attractively, easily, quickly, to the delivery of goods to consumers.

\section{The Pentahelix Model}

Penta Helix defines 5 stakeholders who play an active role in the activities of a particular program or innovation consisting of academics, business, community, government and media. Stakeholder mapping is carried out to see how big the role of each party is in contributing to the success or finding innovations of a business or business activity being carried out. It is hoped that with the active role of this penta helix, synergy can be achieved and obstacles that arise can be overcome in an effort to foster and develop MSMEs (Muhyi, et al, 2017).

\section{SWOT Analysis}

According to Freddy (2013), SWOT analysis is an analysis based on logic that can maximize strengths and opportunities (Opportunity), but at the same time can minimize weaknesses (Weakness) and threats (Threats). According to Galavan (2014), SWOT analysis (Strength, Weakness, Opportunity, and Threat) is an analysis to get a useful strategy or effectively applied according to the market and public conditions at that time, opportunities (Opportunity) and threats (Threats) are used to determine the environment outside or external then strength (Strength) and weakness (Weakness) obtained through analysis within the company or internally.

\section{Previous Research}

Sutrisno and Anitasari (2020) state that Creative Economy Strengthening Strategy With Penta Helix Identification In Bojonegoro Regency. The results of the study show that the active role of the government in seeking the penta helix synergy has not been maximized, the synchronization of academics and the government has not been too serious, so that the results of higher education research are only teaching materials on campus. The role of the community is not yet clearly visible in driving the creative economy. The government has also not focused on providing regulations related to the rules for the use of natural resources.

\section{Method}

This research uses descriptive qualitative research through an phenomenological approach. The phenomenological approach is an approach related to reality for analyzing the situation in it. Data mining was carried out through depth interviews, focus group discussions and observation. The informants in this study were 15 people who were included in the pentahelix consisting of government (cooperative and MSME service), business/entrepreneurs (craft, arts, culinary and fashion entrepreneurs), academicians, community and media. 
The types and sources of data in this study are primary data, namely data directly from the source, namely the government/government (dekranasda of Deli Serdang district, the Department of Industry and Trade, the cooperatives and SMEs office, the BUMN as a form of corporate social responsibility), business/entrepreneurs (entrepreneurs). craft, arts, culinary and fashion), academicians/academics, commmunity/community and media.

Data analized by using interactive data analysis consist of three main things, namely: data reduction, data presentation, and conclusion.This study uses source triangulation which seeks to find the truth of information through various sources such as interviews, documents, archives, observations, as well as by interviewing more than one source of information that has different points of view. The data from the interviews were collected and then identified the same answers to the interview questions. After that, a focus group discussion was conducted to obtain conclusions. SWOT analysis technique used to find out the best strategy to overcome obstacles in strenghtening the creative economy.

\section{Results and Discussions}

This research was conducted in Percut Sei Tuan Sub-district, taking samples of 3 villages from a total of 20 villages consisting of Bandar Khalippa, Percut, and Desa Kolam engaged in the creative economy sector of craftsmen/crafts, arts, culinary and fashion subsectors. The research was conducted through in-depth interviews with informants from the Pentahelix model consisting of academics in this case from the University of North Sumatra, namely Prof. Dr. Ritha Dalimunthe, entrepreneurs in the creative economy sub-sector consist of furniture entrepreneurs (Mr. Bambang Surato), sweet potato and banana chips entrepreneurs (Misniati), performing arts entrepreneurs (Aditya Sena) and batik entrepreneurs (Rahmawaty), shell lamp entrepreneurs (Poniman), salty fish entrepreneurs (Hasrani).In this case, the goverment consist of the Head of the Deli Serdang Cooperative and MSMEs Service (Dra. Hj. Rabiatul Adawiyah Lubis, M.Pd), Percut Sei Tuan Sub-district Head (Mr. Ismail SSTP, MSP), Percut village head (Mr. Ashari Syah), Desa Kolam head (Mr. Jupri Purwanto), the community (Creative Economy Agency, Multi-Business Cooperative) and the media (in this case the Kominfo represented by Mr. Safi'i Sihombing, S.IP, M.AP. After the interview was conducted and obtained data regarding the development of MSMEs in the area, the next step is conduct focus group discussions to discuss more deeply the data has been obtained to get the final results of the research.

The research results are obtained as follows:

a. From the results of interviews with business actors, there has been a very significant decline in sales during the COVID 19 pandemic from 2020 until now. The decline in sales turnover reached an average of $70 \%$ due to reduced purchasing power of the people, followed by a reduction in the number of workers because they were unable to pay labor wages.

b. The obstacles faced in strengthening the creative economy sub-sector based on digital entrepreneurship in Percut Sei Tuan District are:

- Human resources who have not been able to market products using digital technology, where most of these creative economy actors have a junior-high school education background. There have been efforts from the government to help sell goods digitally through training, but the result has not much changed after the training.

- Limited raw materials, especially for the craft/craft and fashion sub-sectors.

This is related to scarcity, because if you have to buy from Java for the furniture craft industry, the selling price will be more expensive and cannot compete with similar entrepreneurs in Percut Sei sub-district. For fashion businesses, especially batik cloth, has the same thing, where the original color raw material from the sap of the mangrove tree is not always available naturally/ 
- The implementation of marketing promotions is still lacking especially with the COVID-19 pandemic conditions, also the unknown about online marketing, so that direct marketing is carried out with the limitations of meeting directly with consumers causes sales turnover decrease.

- Limited working capital is a classic problem faced by creative business actors, due to the unknown about the preparation of financial statements so that it is difficult for banks to provide loans.

- No training incentives have been carried out in regarding the calculation of profits and costs, so there are still many business actors who have not separated business finances from private consumption (business management), while actually there has already been an accounting application technology for MSMEs.

- There is no media to sell products online because they do not have information or knowledge in online marketing/digital entrepreneurship. The media through the Ministry of Communication and Information has attempted to assist business actors in marketing their products but have not been followed consistently due to limited ability to apply digital marketing, and also because they do not sell g products online because they do not have information or knowledge in online marketing/digital entrepreneurship.

- Most of the efforts carried out still conventional, there has not been tried to reach optimal sales turnover and profits (run the business as it is, there is no target in sales)

- Synergy that has not been optimal between the parties involved (pentahelix) so that it seems run independently, which in the end the business development of business actors also tends to be slow, because there is no intervention from parties that can accelerate business growth.

c. Form of collaboration between stakeholders is not maximize.

Based on the results of the focus group discussion, it was found that each stakeholder in the pentahelix model has a view of the need for intensive collaboration or collaboration with one another, so that they can synergize to improve the economic activity carried out by creative business actors in villages in the sub-district. Percut Sei Tuan. It is not enough if the roles are played by each stakeholder, but there must be coordination and collaboration that are complementary in nature so that the obstacles encountered in business management both in terms of production, marketing and finance can be resolved, at least minimized.

The collaboration processes that can be carried out are:

1. Formal and informal dialogue between interested parties in the pentahelix to determine the direction of strengthening the creative economy.

The dialogue that has been carried out so far has not had a high frequency, although it has been done frequently. For this reason, it is necessary to increase the intensity of the dialogue so that business development can be monitored more deeply and problem solving can be carried out more quickly.

2. Shared understanding and perception in advancing creative business actors, marked by frequent meetings and intense communication between stakeholders regarding developments and problems as well as solutions that can be taken to advance the creative economy, also having the same understanding in capturing every problem and situation that arises. occur so that they can be cooperative in solving them.

3. Consistently produce outcomes (outcomes) in every process carried out.

In this case, it is better if the production results that have been produced within a certain period, for example 1 month, can be identified and creative activities or events made, also included in social media so that they can reach a wider marketing area. The progress of the business activities carried out is made in one activity such as exhibitions of goods produced by handicrafts, culinary, and fashion so that the tangible results of the production carried out, whether successfully marketed to the target audience or not, can be seen in real outputs and 
outcomes. So far, sales made by entrepreneurs in the villages of the Percut Sei Tuan subdistrict are still using direct marketing and only a few businesses have used e-marketing facilities.

d.The best strategy that can be chosen in strengthening the creative economy based on digital entrepreneurship in Percut Sei Tuan district through a SWOT analysis involving stakeholders from pentahelix, through interviews and focus group discussions to find out the strengths, weaknesses, opportunities and threats of the condition of business actors in relation to digital entrepreneurship.through the calculation of Weights and Ratings for IFAS and EFAS in Table 1.

Table 1.Calculation of Weights and Ratings for IFAS and EFAS

\begin{tabular}{|c|c|c|c|c|c|}
\hline \multirow{2}{*}{ No } & Strength & \multirow{2}{*}{ Total } & \multirow{2}{*}{ Rating } & Weight & \multirow{2}{*}{$\begin{array}{l}\text { Rating x } \\
\text { Weight }\end{array}$} \\
\hline & Factor & & & $\%$ & \\
\hline 1 & $\begin{array}{l}\text { Digital MSMEs are able to reach a } \\
\text { wider marketing area, both } \\
\text { nationally and internationally }\end{array}$ & 56 & 4 & 0.1470 & 0.588 \\
\hline \multirow{3}{*}{3} & $\begin{array}{l}\text { Business people have superior } \\
\text { products that other business actors } \\
\text { do not have }\end{array}$ & 50 & 3 & 0.1312 & 0.394 \\
\hline & $\begin{array}{l}\text { Digital business actors have faster } \\
\text { access to estimate the number and } \\
\text { target consumers. }\end{array}$ & & & & \\
\hline & & 58 & 4 & 0.1522 & 0.609 \\
\hline \multirow[t]{2}{*}{4} & $\begin{array}{l}\text { Availability of e-commerce } \\
\text { services for business actors such } \\
\text { as Shoppee. Lazada. Tokopedia } \\
\text { that makes buying and selling } \\
\text { transactions easy }\end{array}$ & 57 & 4 & 0.1496 & 0.598 \\
\hline & Total power score & 221 & & 0.580 & 2.19 \\
\hline \multirow{2}{*}{ No } & Weakness & \multirow{2}{*}{ Total } & \multirow{2}{*}{ Rating } & Bobot & \multirow{2}{*}{$\begin{array}{l}\text { Rating } \mathrm{x} \\
\text { Bobot }\end{array}$} \\
\hline & Factor & & & $\%$ & \\
\hline 1 & $\begin{array}{l}\text { Limited raw materials in the } \\
\text { production of goods }\end{array}$ & 40 & 3 & 0.1050 & 0.315 \\
\hline 2 & $\begin{array}{l}\text { Limited human resources in } \\
\text { carrying out digital } \\
\text { entrepreneurship and knowledge } \\
\text { of social media/internet }\end{array}$ & 25 & 2 & 0.0656 & 0.131 \\
\hline 3 & $\begin{array}{l}\text { Not all creative businesses in } \\
\text { Percut sub-district are able to } \\
\text { market their goods using social } \\
\text { media }\end{array}$ & 27 & 2 & 0.0709 & 0.142 \\
\hline 4 & $\begin{array}{l}\text { The number of wifi access for the } \\
\text { convenience of creative business } \\
\text { actors is still lacking }\end{array}$ & 24 & 2 & 0.0630 & 0.126 \\
\hline 5 & $\begin{array}{l}\text { Limited capital to develop a } \\
\text { business }\end{array}$ & 44 & 3 & 0.1155 & 0.346 \\
\hline
\end{tabular}




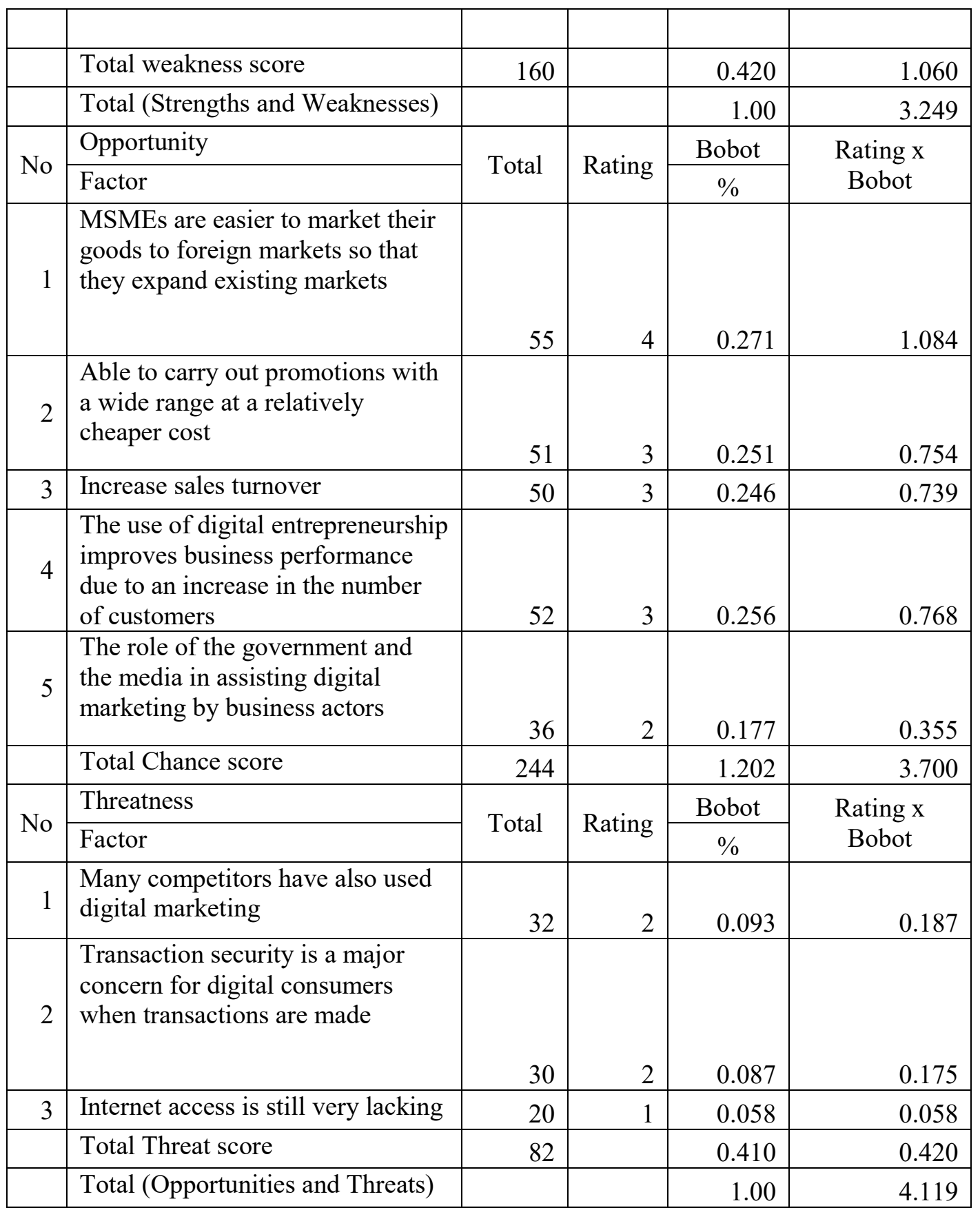

Source: Processed Data (2021)

Furthermore, the determination of alternative strategies based on SWOT analysis is carried out. To determine the position in the SWOT matrix, two calculations are carried out. First, by adding up the total strength score with the total weakness score (IFAS), it is assumed that the strength score is positive, while the weakness score is dominant. If the result is positive, it means that the power factor is more dominant, in this case the IFAS value is $2.19+1.060=$ 3.249. Second, adding up the total opportunity score and the total threat score (EFAS), it is assumed that the opportunity score is positive, while the threat score is dominant. If the result is positive, it means that the opportunity factor is more dominant. Conversely, if the result is dominant, it means that the threat factor is more dominant, with an EFAS value of $3.700+$ $0.420=4.119$ 
From the calculation results of the IFAS and EFAS tables, the IFAS value is 3,249 and the score for the EFAS result is 4,119. When converted into an IE Matrix Diagram image, it is located in quadrant I, where the result is that the company enters the growth phase.

The calculation results of the IFAS and EFAS matrices can be seen from the following table 2:

Table 2. IFAS and EFAS . Matrix Values

\begin{tabular}{|l|l|l|}
\hline & \multicolumn{2}{|c|}{ IFAS } \\
\hline \multicolumn{1}{|c|}{ EFAS } & Strength: 2.19 & Weakness: 1.060 \\
\hline Opportunity: 3,700 & SO: 5,89 & WO: 4,76 \\
\hline Threatness: 0.420 & ST: 2,61 & WT: 1,48 \\
\hline
\end{tabular}

Source: Processed Data (2021)

Alternative strategies are shown in table 2. Based on the SWOT diagram analysis in table 1 and the IFAS and EFAS matrix values in table 2, it can be seen that strengths are greater than weaknesses and opportunities are greater than threats, so the company is in quadrant 1 with the strategy used is a growth strategy.

From the SWOT matrix, 4 main strategies can be drawn up, namely S-O, W-O, S-T, and WT.

a. S-O (Strengths - Opportunities) strategy.

Strength-Opportunity strategy can be done consists of: develop market to overseas, business has product advantages over competitors, promotions are intensively carried out by digital entrepreneurship and production is increased, training was made for business actors.

b. W-O Strategy (Weaknesses - Opportunities)

Weakness-Opportunity strategy consists of increase cooperation with suppliers of raw materials so that the market can be expanded, digital entrepreneurship training is provided so that promotions with a wide range can be carried out, role from the government is needed so that products can be sold through online media, given wifi access in this case the role of the government and community in helping the availability of wifi, given working capital in order business runs smoothly and meet consumer demand.

c. ST Strategy (Strengths-Threats)

In this case, it can concluded that Strength-Threats strategy is consist of: ensure deep guidance from the government as an effort to balance competitors in marketing, especially digital marketing, ensure transaction security by monitoring activities carried out, provide assistance to business actors in accessing wifi.

d. StrategyW-T(Weaknesses-Threats)

In this case, it can concluded that W-T strategy is consist of conducted digital marketing training, supervision of online sales activities is carried out to minimize transaction errors and misuse of technology, the need for the role of various parties who are members of the pentahelix model to overcome the problems of creative business actors

Besides, there are several alternative strategies that can be used in the growth stage, namely:

a. Improving product quality, adding product characteristics and motifs through innovation and creativity.

b. Entering new market segments and continuing to coordinate with the cooperative and

SME offices, as well as the Creative Economy Agency to be able to introduce new products through exhibitions and MSME events, as well as training to improve the skills of business actors. 
c. The government is intensively holding digital entrepreneurship training for business actors so that they are accustomed to doing business using digital entrepreneurship so

that they are able to increase sales volume as well as expand marketing areas.

d. Promote promotion via digital marketing that can reach a larger number of target audiences.

e. Stakeholders in the pentahelix model should always collaborate, synergize with one another so that business actors are accompanied and provided with facilities and ssistance in order to advance their business.

\section{Conclusions}

Conclusions is obtain from the result and discussion namely:

a. The obstacles faced in the development of the creative economy are the inability to market products using digital technology due to lack of knowledge and understanding of digital entrepreneurship, online promotions that have not been carried out, limited availability of raw materials, lack of working capital, the role media in online marketing is not maximize yet, the collaboration among stakeholders that has not been optimal in pentahelix.

b. Based on the SWOT analysis that has been carried out through the identification of the internal and external environment, it is found that the best strategy is a growth strategy that can be done by improving product quality, adding product characteristics and motifs through innovation and creativity, actively holding exhibitions and MSME events, the government holds digital entrepreneurship training to improve the marketing skills of business actors and sales volume, actively promotes promotion via digital marketing that can reach a larger number of target audiences and stakeholders in the pentahelix model should always collaborate with one another so that business actors are accompanied and provided with facilities and assistance in order to advance their business.

\section{References}

Laudon, K. C., \& Traver, C. G. (2017). E-commerce: Business, Technology, Society. Global Edition, Pearson: Harlow, Essex.

Muhyi, H. A., Chan, A., Sukoco, I., \& Herawaty, T. (2017). The Penta Helix Collaboration Model in Developing Centers of Flagship Industry in Bandung City. Review of Integrative Business and Economics Research, 6(1), 412-417.

Purwana, D., Rahmi, R., \& Aditya, S. (2017). Utilization of Digital Marketing for Micro, Small and Medium Enterprises (MSMEs) in Malaka Sari Village, Duren Sawit. Journal of Community Empowerment at Madani (JPMM), 1(1), 1-17. https://doi.org/10.21009/jpmm.001.1.01

Santia, T. (2020). How many MSMEs are there in Indonesia? This is the Count. https://www.liputan6.com/bisnis/read/4346352/berapa-sum-umkm-di-indonesia-inihitungannya. Accessed April 26, 2021

Sukirno, S. (2016). Introduction to Macroeconomic Theory. Jakarta: Rajawali Press.

Sutrisno, S., \& Anitasari, H. (2020). Creative Economy Strengthening Strategy With Penta Helix Identification In Bojonegoro Regency. Scientific Journal of Business Administration and Innovation, 3(2), 89-108. 